\title{
Primjena matematičkog modeliranja u razvoju enzimskih kaskadnih reakcija
}

\author{
N. Milčić, M. Česnik, M. Sudari Z. Findrik Blažević* \\ Sveučilište u Zagrebu, Fakultet kemijskog inženjerstva i tehnologije, \\ Savska c. 16, HR-10 000 Zagreb
}

Ovo djelo je dano na korištenje pod

\begin{abstract}
Sažetak enzimskih kaskadnih reakcija koji pokazuju važnost i potencijal te metodologije.

Ključne riječi

Reakcijsko inženjerstvo, biokataliza, modeliranje, optimizacija, više-enzimski sustavi
\end{abstract}

"Sustavska biokataliza" (engl. systems biocatalysis), odnosno provedba kaskadnih reakcija koje oponašaju stanične metaboličke puteve danas se sve češće primjenjuje. Kaskadne reakcije imaju brojne prednosti nad tradicionalnim kemijskim postupcima, međutim, za uspješnu optimizaciju i prenošenje takvih kompleksnih sustava u veće, industrijsko mjerilo potrebno je primijeniti reakcijsko inženjerstvo. U ovom preglednom radu navedeni su primjeri uspješne primjene matematičkog modeliranja na razvoj

\section{Uvod}

Biokataliza zauzima važan položaj u industriji radi mogućnosti sinteze optički čistih tvari pri blagim reakcijskim uvjetima i kraćim vremenima trajanja reakcija upotrebom biokatalizatora s visokom enantio- $\mathrm{i}$ dijastereoselektivnošću te izvanrednom katalitičkom učinkovitošću. ${ }^{2}$ Noviji koncept biokatalize predstavlja "sustavska biokataliza" (engl. systems biocatalysis) gdje su enzimi organizirani in vitro u kompleksne kaskade u svrhu postizanja učinkovite i održive sinteze vrijednih kemijskih produkata. ${ }^{3}$ Kaskadne reakcije oponašaju stanične metaboličke puteve, a prednost pristupa in vitro je mogućnost upotrebe supstrata $\mathrm{i}$ enzima koji u prirodi ne moraju nužno postojati. Također, primjenom neprirodnih, umjetnih, više-enzimskih kaskada moguće je sintetizirati produkte koje je inače teško dobiti konvencionalnim metodama organske sinteze. ${ }^{4}$ Kaskadne reakcije nude brojne prednosti nad tradicionalnim kemijskim postupcima, poput pojednostavljenja naknadnih procesa obrade bez izolacije međuprodukata, jednostavnijih i ekonomski isplativijih reaktorskih sustava koji se sastoje od samo jednog reaktora, blagih i kontroliranih reakcijskih uvjeta, manje potrošnje kemikalija i smanjenog ukupnog utjecaja na okoliš. ${ }^{5}$ Znanstvena i industrijska zajednica sve više pažnje posvećuju kaskadnim reakcijama, što je očito iz dostupne literature, poput preglednog članka koji obuhvaća sve kaskadne sustave istraživane i objavljene u prošlom desetljeću, ${ }^{6}$ članka o mogućnostima poboljšanja kaskadnih sustava implementacijom inženjerskog pristupa ${ }^{7}$ kao i poglavlja u knjigama. ${ }^{8}$

Novija literatura (nakon 2000. godine) pokazuje širenje opsega znanstveno-istraživačkih tema, za razliku od prije 10 godina, ${ }^{5}$ kao i činjenicu da se matematičko modeliranje i inženjerski pristup sve češće primjenjuju u razvoju

*Autor za dopisivanje: prof. dr. sc. Zvjezdana Findrik Blažević e-pošta: zfindrik@fkit.hr novih kompleksnih biotransformacija. Razlog tomu je složenost više-enzimskih kaskadnih reakcija koje se provode u jednom reaktoru, koja je često podcijenjena. ${ }^{9}$ Reakcijsko inženjerstvo često se primjenjuje za projektiranje i dimenzioniranje reaktora u kemijskoj industriji. ${ }^{10}$ Sukladno tomu, može se očekivati da je isto moguće i pri razvoju procesa u biokatalizi. Nažalost, taj pristup se u praksi još uvijek ne primjenjuje dovoljno jer je za uspostavljanje učinkovitih kaskadnih procesa potrebno uskladiti enzimsku kinetiku, stabilnost biokatalizatora i termodinamiku sustava, ${ }^{4}$ što zahtijeva velike napore za razvoj konkurentnih procesa i zasigurno sprječava širu industrijsku primjenu biokatalize. ${ }^{11}$ Primjenom reakcijskog inženjerstva moguće je skratiti vrijeme trajanja reakcije, smanjiti nastajanje nusprodukata, pozitivno utjecati na enzimsku stabilnost, koncentraciju produkta i ostale procesne značajke. Simulacijama je moguće bez opsežnog eksperimentiranja odrediti koji je tip reaktora najbolji za proučavanu reakciju. Leuchs i sur. ${ }^{12}$ demonstrirali su kako se matematičko modeliranje u biokatalizi može primijeniti ne samo u optimizaciji već i u procjeni ekonomičnosti procesa te njegova utjecaja na okoliš. Kako bi bile konkurentne kemijskoj sintezi, kaskadne reakcije trebaju biti učinkovite, robusne i samoodržavajuće, te bi bilo idealno da se provode in vitro $\mathrm{u}$ jednom reaktoru. ${ }^{13}$ Izazovan zadatak poput ovog zahtijeva primjenu multidisciplinarnih metodologija poput inženjerstva supstrata, reakcijskog medija, proteinskog inženjerstva, formulacije biokatalizatora, biokatalitičke kaskade i reaktora. ${ }^{14,15} \mathrm{U}$ svrhu implementacije procesa, proteinsko i procesno inženjerstvo treba primjenjivati istodobno, budući da nude komplementarna rješenja pri projektiranju procesa ${ }^{4}$ jer proteinsko inženjerstvo može znatno poboljšati parametre enzimske kinetike koji praktički određuju ishod cijelog procesa. Za rješavanje izazova u razvoju kaskadnih reakcija treba primijeniti interdisciplinarni pristup koji objedinjuje kemiju, biologiju i inženjerstvo. Takav pristup zasigurno će utrti put bržoj komercijalizaciji biotehnoloških rješenja. ${ }^{16}$ 


\section{Razvoj enzimskog kaskadnog sustava}

Dok se u literaturi ${ }^{7}$ razmatraju razne tehnološke mogućnosti i općenite strategije razvoja više-enzimskih kaskadnih reakcija vezane uz izbor oblika enzima, reaktorskih i procesnih opcija te radnih uvjeta, fokus ovog rada je na modeliranju i optimizaciji procesa pomoću modela. Prvi korak kod uspostavljanja više-enzimskih sustava u jednom reaktoru je odabir odgovarajućih pufera i temperature zbog različitih ovisnosti aktivnosti enzima o $\mathrm{pH}$ vrijednosti i temperaturi. Odabir optimalnih reakcijskih uvjeta predstavlja pronalaženje kompromisa odnosno radnih uvjeta pri kojima će svi enzimi biti dovoljno aktivni. Idući korak je detaljna evaluacija kinetike pojedinih reakcija u kaskadi pri odabranim uvjetima i procjena kinetičkih parametara. Kinetička ispitivanja su ključni dio temeljnih istraživanja u razvoju (bio)kemijskih procesa jer osiguravaju bolje razumijevanje reakcije i omogućuju uvid u ovisnosti reakcijskih brzina o koncentracijama tvari koje sudjeluju u reakciji. ${ }^{17}$ Za cjelovit i precizan model potrebno je procijeniti utjecaj svih komponenti prisutnih u reakcijskom sustavu na svaki pojedinačni enzim. To je potrebno jer supstrati i produkti jedne enzimske reakcije mogu imati negativan utjecaj na drugu reakciju i obrnuto. Također, enzimi u kaskadama mogu sudjelovati u neželjenim reakcijama sa supstratima i/ili produktima nekog drugog reakcijskog stupnja, što je također potrebno ispitati. U tom slučaju, kaskadu ne treba provoditi u jednom reaktoru, da se reakcije odvijaju istodobno, već reakcijske stupnjeve treba provoditi odvojeno.

Kinetički parametri služe kao osnova za razvoj kinetičkih modela. U kombinaciji s bilancama tvari za određeni reaktor, oni predstavljaju cjelokupan matematički model reakcijskog sustava. Matematički model tada se može primjenjivati za preliminarne simulacije te za odlučivanje o početnim uvjetima eksperimenata. Ocjena valjanosti modela može rezultirati neslaganjima s eksperimentalnim podatcima, što je čest slučaj s enzimima koji gube svoju aktivnost tijekom vremena. U takvim slučajevima potrebno je provesti dodatne eksperimente za procjenu enzimske operacijske stabilnosti te konstante deaktivacije enzima koja će, integrirana u model, poboljšati slaganje eksperimentalnih podataka i rezultata simulacija.

U mnogim slučajevima supstrati mogu utjecati na stabilnost enzima, ${ }^{18-22}$ stoga je važno ispitati te utjecaje i uključiti potrebne jednadžbe u matematički model. Simulacijama je također moguće ocijeniti može li se proces poboljšati s povremenim dodatkom svježeg enzima u reaktor ili čak je li takav postupak ekonomski opravdan. Primjenom matematičkog modela moguće je simulirati različite scenarije reakcija u različitim tipovima reaktora, različite strategije dotoka supstrata i/ili enzima sa stajališta procesnih značajki kao i s ekonomskog stajališta. Takva procjena može biti komplicirana čak i u sustavu s jednim enzimom, dok u više-enzimskim kaskadnim sustavima broj interakcija raste. ${ }^{7}$ Naposljetku, kada su poznate sve međuovisnosti između procesnih varijabli i kada je model eksperimentalno validiran, može se primjenjivati za optimizaciju procesa. Pomoću modela mogu se predvidjeti reakcijski profili u različitim tipovima reaktora i pri različitim uvjetima te na taj način odabrati odgovarajući tip reaktora, procesne uvjete i optimirati sustav. Dodatno, uspostavljanje kinetičkih modela pojedinih reakcijskih stupnjeva dopušta njihovu upotrebu u modularnom obliku, tj. jedan enzim u reakciji može se lako zamijeniti drugim enzimom s odgovarajućim kinetičkim parametrima. Time je također omogućen odabir najboljeg enzima pomoću simulacija. Analiza osjetljivosti parametara može pomoći u pronalaženju parametara koji najviše utječu na ishod reakcije..$^{23} \mathrm{U}$ skladu s time, odabrani parametri mogu biti poboljšani proteinskim inženjerstvom. Primjenom takvog cjelovitog pristupa i analize, modeliranje se može primijeniti za uvećanje procesa. Takav pristup modeliranju može se pronaći u postojećoj literaturi koja obuhvaća više-enzimske kaskadne reakcije, što je ujedno tema idućeg poglavlja u kojem je primjena modeliranja demonstrirana primjerima iz literature.

\section{Primjeri primjene modeliranja u razvoju enzimskih kaskadnih reakcija}

\subsection{Sustavi s dva enzima}

Najveći broj sustava s dva enzima za koje su razvijeni kinetički modeli predstavljaju reakcije katalizirane oksidoreduktazama koje zahtijevaju regeneraciju koenzima. ${ }^{24-29}$ Takve reakcije se često primjenjuju za proizvodnju kiralnih produkata, ${ }^{28,30-32}$ u oksidacijama kataliziranim oksidoreduktazama, ${ }^{26,29}$ itd. U reakcijama oksidacije mnogo je teže uspostaviti učinkovit sustav regeneracije i, posljedično, postići industrijsku primjenjivost. NADH oksidaza, enzim koji se upotrebljava u tim regeneracijama, zahtjeva aeraciju, a osjetljivost enzima na kisik ili međufaznu površinu plin-kapljevina ${ }^{33-35}$ čini takav sustav kompliciranim. Iz tog razloga razmatraju se drugi načini regeneracije koji uključuju prisutnost kosupstrata ili drugog enzima. Kako bi se uspješno provela regeneracija, reakcija regeneracije treba biti znatno brža od glavne reakcije. To znači da potreban oblik koenzima u reaktoru treba uvijek biti dostupan u maksimalnoj (početnoj) koncentraciji; do $1 \mathrm{mmol} \mathrm{dm}^{-3}$ jer se u reaktor dodaju znatno niže koncentracije koenzima od koncentracija supstrata u glavnoj reakciji. Oblik koenzima suprotan obliku koji je potreban za provođenje glavne reakcije često je inhibitor kako u glavnoj reakciji tako i u reakciji regeneracije..$^{24,25,29}$ Prema tome, ta inhibicija može biti svedena na minimum samo u slučaju primjene uspješnog i učinkovitog regeneracijskog sustava. $U$ redukcijama kataliziranim oksidoreduktazama, dobro utemeljena i uobičajena metoda $\mathrm{NAD}(\mathrm{P}) \mathrm{H}$ regeneracije uključuje upotrebu formijat-dehidrogenaza. Mogu se upotrebljavati i drugi enzimi, ali u kombinaciji s kosupstratima i koproduktima. ${ }^{36}$

U literaturi postoje i drugi reakcijski sustavi s dva enzima opisani matematičkim modelom. Chen $i$ sur. ${ }^{37}$ pokazali su potencijal primjene modeliranja na primjeru sinteze aminotriola (shema 1) katalizirane enzimima transketolazom i transaminazom. Njihov model, iako samo teoretski s reprezentativnim parametrima, pružio im je korisne informacije preko simulacija. Model uključuje kinetiku enzimske reakcije, raspad reakcijskih komponenti, ali i toksičnost aldehida, supstrata u ispitivanoj reakciji, prema enzimu. Rios-Solis $i$ sur. ${ }^{38}$ istraživali su slične reakcijske sustave za sintezu istog produkta (i sličnog alternativnog produkta). Osim eksperimentalnog ispitivanja, spojili su prednosti modeliranja i sintetske biologije u svrhu poboljšanja kaskade. Procijenili su kinetičke parametre za oba enzima 


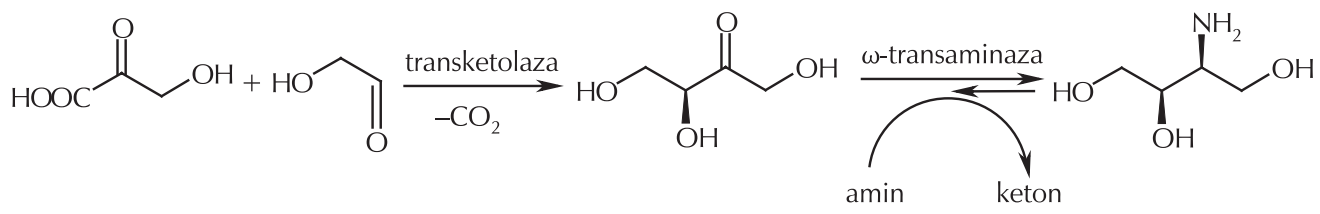

Shema 1 - Sinteza 2-amino-1,3,4-butanetriola u kaskadnoj reakciji ${ }^{37}$

Scheme 1 - Synthesis of 2-amino-1,3,4-butanetriol in a cascade reaction ${ }^{37}$

u kaskadi te su kasnije prekomjerno izrazili oba enzima u istoj bakteriji uz postavljanje željene razine aktivnosti oba enzima u stanicama, koje su prethodno određene primjenom kinetičkog modela. Kinetički model primijenjen je za optimizaciju strategije dotoka amino-donora u kotlasti reaktor s dotokom kako bi se prevladala nepovoljna ravnoteža reakcije. Primjenom takvog pristupa, sinteza je uspješno provedena na preparativnoj skali te je dobiveno šest puta veće iskorištenje na produktu u odnosu na neoptimiran reakcijski sustav (tablica 1).

Primjenu matematičkog modeliranja za uvećavanje procesa (100 puta) u kaskadnoj reakciji pokazali su Van Hecke i sur. ${ }^{34,53}$ Istraživali su sintezu laktobionske kiseline u reakciji kataliziranoj celobioza-dehidrogenazom. Pri tome je lakaza upotrijebljena kao enzim za regeneraciju koenzima. Reakcija je provedena u aeriranom reaktoru s dinamičkom membranom koji je radio kao protočno kotlasti reaktor. Autori su primijenili model razvijen na malom mjerilu $u$ kotlastom reaktoru kako bi pronašli odgovarajuće uvjete za provedbu procesa u protočno kotlastom reaktoru većeg volumena. Primjenom modela ispitan je i utjecaj $k_{\mathrm{L}} \mathrm{a}^{\prime}$ na proces. Ovaj rad pokazuje da je moguće "pojednostaviti" složene sustave primjenom modela, uravnotežiti varijable procesa kao što su enzimske aktivnosti, koncentracija redoks medijatora, brzina protoka i prijenosa kisika, koncentracija supstrata i protok smjese u dotoku te primijeniti model na velikom mjerilu. Pri optimalnim uvjetima postignuta je volumna produktivnost od $74,4 \mathrm{~g} \mathrm{I}^{-1} \mathrm{~d}^{-1}$ i konverzija veća od $97 \%{ }^{34,53}$ (tablica 1 ).

Zheng i sur. ${ }^{40}$ razvili su polu-mehanistički model za enzimsku hidrolizu lignocelulozne biomase, uz katalizatore celulazu i $\beta$-glukozidazu. Njihov model, koji je uključivao

Tablica 1 - Relevantni procesni parametri proučavanih više-enzimskih kaskadnih sustava

Table 1 - Process relevant parameters of the investigated multi-enzymatic cascade system

\begin{tabular}{|c|c|c|c|c|c|c|c|}
\hline Reaktor $^{\text {ref }}$ & $C_{\text {supstrat }} / \mathrm{mmol} \mathrm{dm}^{-3}$ & $C_{\text {produkt }} / \mathrm{mmol} \mathrm{dm}^{-3}$ & $Q_{v} /\left.g\right|^{-1} d^{-1}$ & $X / \%$ & $t / h$ & $V_{\text {reaktor }} / \mathrm{ml}$ & Broj. enzima \\
\hline kotlasti s dotokom supstrata ${ }^{38}$ & 200 & 140 & n.a. & 70 & 58,3 & 50 & 2 \\
\hline kotlasti ${ }^{39}$ & 40 i 50 & 5 i 0,7 & n.a. & 60 i 10 & 48 & 5 & 2 (3 koraka) \\
\hline protočno kotlasti ${ }^{34}$ & 100 & $95-98$ & 74,4 & $95-98$ & 12 & 201 & 2 \\
\hline kotlasti $^{40}$ & 296 & 317 & n.a. & n.a. & 168 & 125 & 2 \\
\hline kotlasti s dotokom supstrata ${ }^{41}$ & & $283(6-\mathrm{HHA})$ & 0,044 & $>99$ & 20 & 60 & 3 \\
\hline kotlasti $^{42}$ & 4 & n.a. & n.a. & 100 & 3 & 100 & \\
\hline kotlasti $^{9}$ & 100 & 62,3 & n.a. & 62,3 & 10 & 1 & 3 \\
\hline kotlasti $^{43}$ & 1 & 0,2 & n.a. & 100 & 0,17 & n.a. & 3 \\
\hline kotlasti $^{44}$ & 146 & $\begin{array}{c}146 \mathrm{mmol} \mathrm{dm}^{-3} \\
\text { glukonske kiseline } \\
+146 \mathrm{mmol} \mathrm{dm} \mathrm{m}^{-3} \\
\text { fruktoze }\end{array}$ & 168 & 100 & 3,8 & 2,5 & 3 \\
\hline kotlasti $^{45}$ & 10 & 10 & n.a. & 100 & 2,5 & 25 & 4 \\
\hline kotlasti $^{46}$ & 2 & n.a. & n.a. & $>95$ & 5 & 10 & 3 (5 koraka) \\
\hline kotlasti $^{47}$ & 0,8 & 0,566 & & & 240 & 1 & 5 \\
\hline kotlasti $^{48}$ & 10 & 2,1 & n.a. & $\approx 50$ & 96 & n.a. & \\
\hline kotlasti $^{49}$ & 10 & 7,9 & n.a. & 100 & 72 & $0,1-1$ & 3 \\
\hline kotlasti $^{50}$ & 100 & n.a. & 2,6 & n.a. & 0,3 & n.a. & 10 \\
\hline kotlasti $^{51}$ & 350 & 329,7 & 17,0 & n.a. & 150 & 2 & 13 \\
\hline kotlasti $^{52}$ & 0,5 & $\approx 0,47$ & n.a. & 100 & 2 & $\approx 3$ & 5 \\
\hline
\end{tabular}


homogenu reakciju nastajanja glukoze iz celuloze, dvije heterogene reakcije nastajanja celobioze i glukoze iz celuloze, kao i adsorpciju celuloze na prethodno kemijski obrađeni celulozni materijal, opisao je složenost hidrolize lignoceluloznog supstrata te ga je moguće primjenjivati kao robustan alat za simulaciju hidrolize lignoceluloznog materijala.

\subsection{Sustavi s tri enzima}

Scherkus i sur. ${ }^{41}$ su proučavali trostupnjevitu enzimsku kaskadu za sintezu $\varepsilon$-kaprolaktona (shema 2) u kojoj alkohol-dehidrogenaza (ADH) katalizira oksidaciju cikloheksanola, cikloheksanon-monooksigenaza (CHMO) katalizira oksidaciju nastalog cikloheksanona, a lipaza katalizira hidrolizu $\varepsilon$-kaprolaktona u 6-hidroksiheksansku kiselinu.

Kinetički model je primijenjen za procjenu međuovisnosti procesnih varijabli te za odabir odgovarajućeg reaktora. Zbog inhibicije enzima CHMO cikloheksanolom, kao optimalna konfiguracija odabran je kotlasti reaktor s dotokom supstrata. Također je primijećeno i da produkt $\varepsilon$-kaprolakton inhibira CHMO, pa je ta reakcija kombinirana s hidrolizom kataliziranom lipazom u kojem nastaje 6-hidroksiheksanoat čime je poboljšana produktivnost, a i ravnoteža reakcije je pomaknuta u smjeru nastajanja produkta (tablica 1). Bez poznavanja kinetike procesa, optimizacija ili izbor odgovarajućeg reaktora bili bi onemogućeni, odnosno ispitivanje bi se moralo provoditi metodom pokušaja i pogreške, što iziskuje mnogo vremena. ${ }^{41}$

Milker i sur. ${ }^{42}$ također su proučavali sintezu $\varepsilon$-kaprolaktona upotrebljavajući cikloheksenol kao početni supstrat. Oni su po prvi put pokazali da se kinetika kaskadnog sustava određena in vitro može primijeniti za razumijevanje in vivo redoks kaskade. Modeliranje su primjenjivali za identifikaciju uskih grla procesa, njihovo razumijevanje i pronalaženje načina za njihovo rješavanje. Kinetičke konstante procijenjene in vitro upotrijebljene su za optimizaciju ka- skade provedene unutar stanica in vivo. Također, taj model je primijenjen za određivanje potrebne koncentracije enzima u živim stanicama, što predstavlja važan parametar za optimizaciju kaskadnih reakcija. U ovom radu upotrijebljene su niske koncentracije supstrata u rasponu od nekoliko $\mathrm{mmol} \mathrm{dm}^{-3}$, što u osnovi simulira proces u živim stanicama. Predviđanja i hipoteze postavljene na temelju modela potvrđeni su i eksperimentalno. ${ }^{42}$

Zhong i sur. ${ }^{9}$ su proučavali kaskadnu reakciju s tri enzima u jednom reaktoru za proizvodnju celobioze, funkcionalnog zaslađivača. Kinetički model je primijenjen za otkrivanje složenih interakcija između upotrijebljena tri enzima te za određivanje najboljeg omjera enzimskih aktivnosti u reaktoru. Primjenom simulacija, autori su uspjeli skratiti vrijeme reakcije tri puta, na 10 sati, procijenili su učinak inhibicije fosfata na celobioza-fosforilazu i učinak saharoze na iskorištenje na celobiozi za koji je utvrđeno da je ključan za konačni ishod reakcije.

Ishii $i$ sur. ${ }^{43}$ su rekonstruirali metabolički put od glukoze do fruktozadifosfata in vitro. Osim kinetike enzima, njihov model je uključivao i deaktivaciju glukokinaze. Ovaj rad pokazuje da je moguće razviti općeniti metabolički model živih stanica primjenom parametara određenih u okolini koja oponaša in vivo sustav. ${ }^{43}$ Budući da je tema povezana s metabolizmom stanica, upotrijebljene koncentracije su bile oko $1 \mathrm{mmol} \mathrm{dm}^{-3}$ (tablica 1$)$.

Mafra i sur. ${ }^{44}$ upotrijebili su aerirani reaktor za proizvodnju glukonske kiseline i fruktoze iz saharoze u kaskadi s tri enzima (shema 3). Razvijeni kinetički model primijenjen je kako bi se smanjile, tj. optimirale koncentracije enzima potrebne za postizanje maksimalne volumne produktivnosti. Primjenom modela postignuta je velika volumna produktivnost od $7 \mathrm{gl}^{-1} \mathrm{~h}^{-1}$ te $100 \%$-tna konverzija $50 \mathrm{~g} \mathrm{I}^{-1}$ saharoze u glukonsku kiselinu. ${ }^{44}$

Dvorak i sur. ${ }^{46}$ kombinirali su kinetičko modeliranje i proteinsko inženjerstvo kako bi poboljšali iskorištenje kaskadne

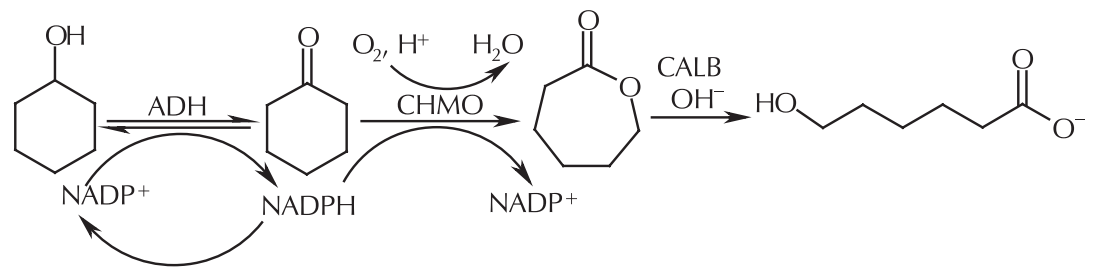

Shema 2 - Sinteza $\varepsilon$-kaprolaktona i 6-hidroksiheksanoata ${ }^{41}$ Scheme 2 - Synthesis of $\varepsilon$-caprolactone and 6-hydroxyhexanoate ${ }^{41}$

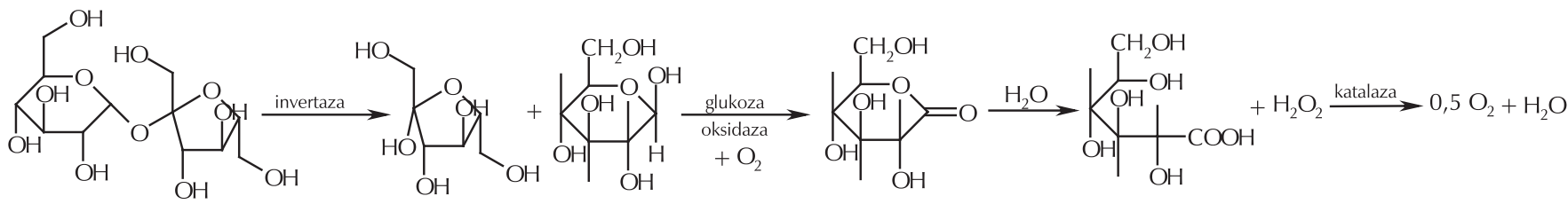

Shema 3 - Biotransformacija saharoze u glukonsku kiselinu u sustavu s tri enzima ${ }^{44}$ Scheme 3 - Biotransformation of sucrose into gluconic acid in a three-enzyme system ${ }^{44}$ 


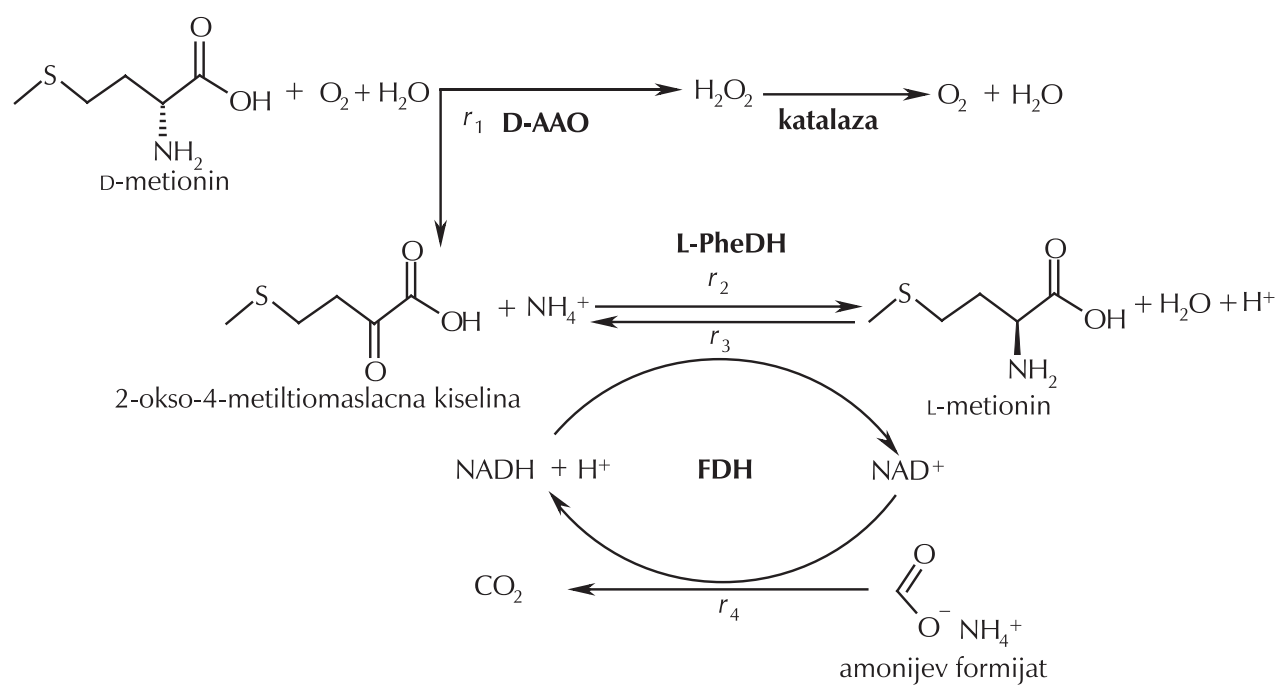

Shema 4 - Biotransformacija D-metionina u L-metionin u sustavu s četiri enzima ${ }^{45}$

Scheme 4 - Biotransformation of D-methionine into L-methionine in a four-enzyme system ${ }^{45}$

reakcije od pet stupnjeva. Istraživali su reakciju pretvorbe 1,2,3-trikloropropana (TCP), toksičnog industrijskog otpada, u glicerol (GLY). Validirani model je primijenjen za predviđanje potrebne koncentracije enzima za postizanje $95 \%$-tne konverzije. Tim radom autori su pokazali da je moguće kombinirati modeliranje i proteinsko inženjerstvo. Dok je kinetičko modeliranje pružilo informacije o potrebnim koncentracijama enzima, proteinskim inženjerstvom jednog od enzima, za koji je utvrđeno da predstavlja usko grlo zbog niske selektivnosti prema supstratu, postignuto je daljnje poboljšanje rezultata i ekonomske učinkovitosti. $\mathrm{Na}$ taj način je potrebna količina katalizatora smanjena za dodatnih $56 \%$ u usporedbi s prirodnim enzimom iz divljeg tipa mikroorganizma, što predstavlja značajan ekonomski učinak za potencijalnu industrijsku primjenu.

\subsection{Sustavi s četiri enzima}

Findrik i Vasić-Račkit5 istraživali su dinamičku kinetičku rezoluciju D-aminokiseline u L-aminokiselinu u kaskadi s četiri enzima (shema 4). Provedena je detaljna kinetička analiza te je matematički model primijenjen za pronalazak odgovarajućih koncentracija enzima, koenzima i kosupstrata potrebnih za postizanje potpune konverzije jednog enantiomera u drugi. Taj sustav je moguće primjenjivati za pretvorbu racemičnih smjesa aminokiselina u L-enantiomer.

\subsection{Sustavi s pet enzima}

Transformacija modelnog spoja lignina $u$ aromatske spojeve proučavana je u kaskadnoj reakciji s pet enzima, ${ }^{52}$ a modeliran je samo dio kaskadne reakcije koja uključuje $\mathrm{NAD}^{+}$ovisnu $\mathrm{C}-\alpha$-dehidrogenazu zajedno sa sustavom za regeneraciju u svrhu optimizacije i postizanja potpune konverzije supstrata. Upotrijebljena je koncentracija supstrata od $0,5 \mathrm{mmol} \mathrm{dm}^{-3}$.
Rexer i sur. ${ }^{47}$ su proučavali kaskadnu reakciju s pet enzima (shema 5) za proizvodnju i regeneraciju GDP-manoze iz manoze i polifosfata uz upotrebu katalitičkih količina GDP-a i ADP-a. Razvili su i primijenili kinetički model za optimizaciju kaskade, te je dobiveno $71 \%$-tno iskorištenje na GDP-manozi. Njihov model moguće je kombinirati sa sustavom koji sadrži jednu ili više glikoziltransferaze i predstavlja prvi korak prema razvoju proizvodnje oligosaharida vezanih lipidima kao prekursora za in vitro gliko-inženjering proteina.

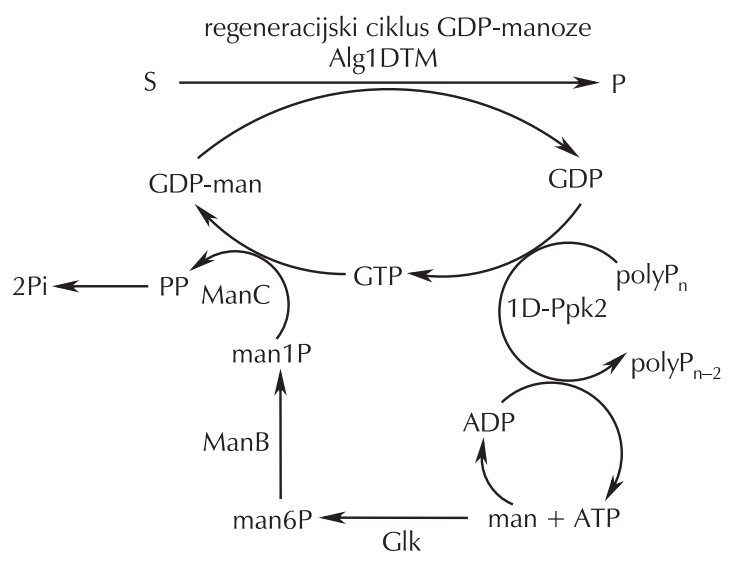

Shema 5 - Regeneracija GDP-manoze u kaskadi s pet enzima ${ }^{47}$ Scheme 5 - Regeneration of GDP-mannose in a five-enzyme cascade $^{47}$

\section{Alternativni inženjerski pristup u proučavanju kaskadnih reakcija}

Pristup temeljen na modeliranju, prikazan u prethodnim poglavljima, može znatno smanjiti potrebu za eksperimentalnim radom, kao i troškove razvoja procesa. ${ }^{26}$ Međutim, 
u slučajevima kada su potrebne kemikalije nedostupne ili u sustavu dolazi do nastajanja nusprodukata i usporednog odvijanja neželjenih reakcija, taj pristup nije moguće primjenjivati. U takvim situacijama moguće je upotrijebiti dizajn eksperimenata primjenom statističkih ili stohastičkih metoda te optimirati proces također uz manji broj potrebnih eksperimenata.

Hoh i sur. ${ }^{48}$ primijenili su genetički algoritam kao stohastičku metodu za optimizaciju kaskadnog sustava s dva enzima u svrhu sinteze $O$-glikanske jezgre strukture 2. Optimiranje te reakcije izazovno je zbog mnogih inhibicija i slabe regioselektivnosti enzima, zbog čega je bilo teško razviti primjenjiv kinetički model. Autori su optimirali sedam varijabli koje uključuju koncentraciju enzima, pH vrijednost, temperaturu te koncentracije supstrata i koenzima, čime su povećali selektivnost reakcije s 34 na $74 \%$ nakon samo četiri generacije eksperimenata, što bi vrlo vjerojatno bilo neizvedivo metodom pokušaja i pogreške. Prednost upotrebe genetičkog algoritma proizlazi iz istodobnog optimiranja velikog broja varijabli. ${ }^{54}$

Sudar i sur..$^{49}$ pokazali su kako se složena kaskadna reakcija može optimirati pomoću statističkog modela. Ispitana je kaskadna reakcija sinteze aldolnog adukta (3S,4R)-6-[(benziloksikarbonil)amino]-5,6-dideoksiheks-2-uloze iz supstrata Cbz-N-3-aminopropanola (shema 6). Spoj se oksidira u odgovarajući aldehid, koji se troši in situ u sljedećem koraku aldolne adicije na dihidroksiaceton. Alkohol-dehidrogenaza, biokatalizator upotrijebljen za oksidaciju alkohola, također katalizira sporednu reakciju oksidacije aldehida, tvoreći neželjeni kiselinski nusprodukt. U radu je primijenjeno statističko modeliranje upotrebom dizajna eksperimenata. Pažljiv odabir raspona varijabli presudan je za ishod prilikom dizajniranja eksperimenata. $U$ ovom je slučaju od velike koristi bilo iskustvo istraživačke grupe s regeneracijom koenzima i s kinetikom oksidacija kataliziranih oksidoreduktazama, posebno pri odabiru raspona varijabli i dizajna procesa. Kao rezultat te metode, iskorištenje na produktu je poboljšano na $79 \%$, pri čemu je nastajanje kiseline znatno smanjeno (tablica 1).

Kako bi sintetizirali 2-amino-1,3,4-butantriol, Villegas-Torres i sur. ${ }^{39}$ primijenili su metodu statističkog dizajna za kaskadnu reakciju s dva enzima i za kaskadu koju čine tri slijedne reakcije (shema 7). Pri određivanju optimalnih reakcijskih uvjeta ( $\mathrm{pH}$ vrijednost, temperatura i pufer) primijenjena je kombinacija eksperimenata na mikro skali i statistički eksperimentalni dizajn, dok je za optimizaciju koncentracije supstrata i enzima primijenjena metodologija odzivne površine ${ }^{39}$, čime je smanjen broj potrebnih eksperimenata prilikom optimiranja reakcijskog sustava. To je istraživanje provedeno u svrhu buduće primjene genetičkog inženjerstva na soj bakterije koja sadrži oba enzima. Zbog nemogućnosti provedbe detaljne analize podataka kojom bi se procijenilo pokazuje li određeni spoj inhibicijski učinak na jedan ili više enzima te dolazi li do deaktivacije enzima, to je istraživanje kao rezultat iznijelo samo općenite zaključke o utjecaju pojedinih varijabli i njihovih međuovisnosti na ciljeve optimizacije procesa. Ipak, tim su pristupom autori uspjeli povećati konverziju s 30 na $60 \%$ u slučaju prve kaskade (shema 2A) i s 1 na $3 \%$ (shema 2B) u slučaju druge kaskade ${ }^{39}$ (tablica 1).

Kako bi proizveli plinoviti vodik, Rollin i sur. ${ }^{50}$ upotrijebili su deset pročišćenih enzima te kreirali složenu kaskadnu reakciju kakva ne postoji u prirodi. Početni supstrati te reakcije su šećeri iz biomase, ksilan i glukoza. Kinetički parametri modela procijenjeni su pomoću genetičkog algoritma, ${ }^{55}$ a za odabir enzima s najvećim utjecajem na brzinu i iskorištenje reakcije primijenjena je analiza osjetljivosti. $\mathrm{Na}$ temelju njihovog pristupa i simulacija modela te nakon optimiranja količine upotrijebljenih enzima, postignuta je tri puta veća produktivnost vodika od $32 \mathrm{mmoll}^{-1} \mathrm{~h}^{-1}$. Daljnje povećanje do $54 \mathrm{mmol} \mathrm{I}^{-1} \mathrm{~h}^{-1}$ vodika dobiveno je nakon optimiranja temperature i koncentracije supstrata i enzima. Dobivena produktivnost usporediva je s industrijskom proizvodnjom bioplina i vodika. ${ }^{56}$

Ardao i Zeng ${ }^{51}$ također su proučavali proizvodnju vodika iz biomase uspoređujući in silico procese. Njihov se pristup temelji na reakciji u kojoj se upotrebljava trinaest enzima. Optimizacija te reakcije provedena je primjenom genetičkog algoritma s produktivnošću i iskorištenjem kao funkcijama cilja. Pronađeni su uvjeti procesa pri kojima se ostvaruje produktivnost od $355 \mathrm{mmol} \mathrm{I}^{-1} \mathrm{~h}^{-1}$ vodika bez smanjenja prethodno ostvarenog iskorištenja od 94,2 \% (tablica 1). Treba naglasiti da su autori primjenom takvog pristupa pri optimizaciji procesa istodobno mogli optimirati šesnaest varijabli koje uključuju količine biokatalizatora

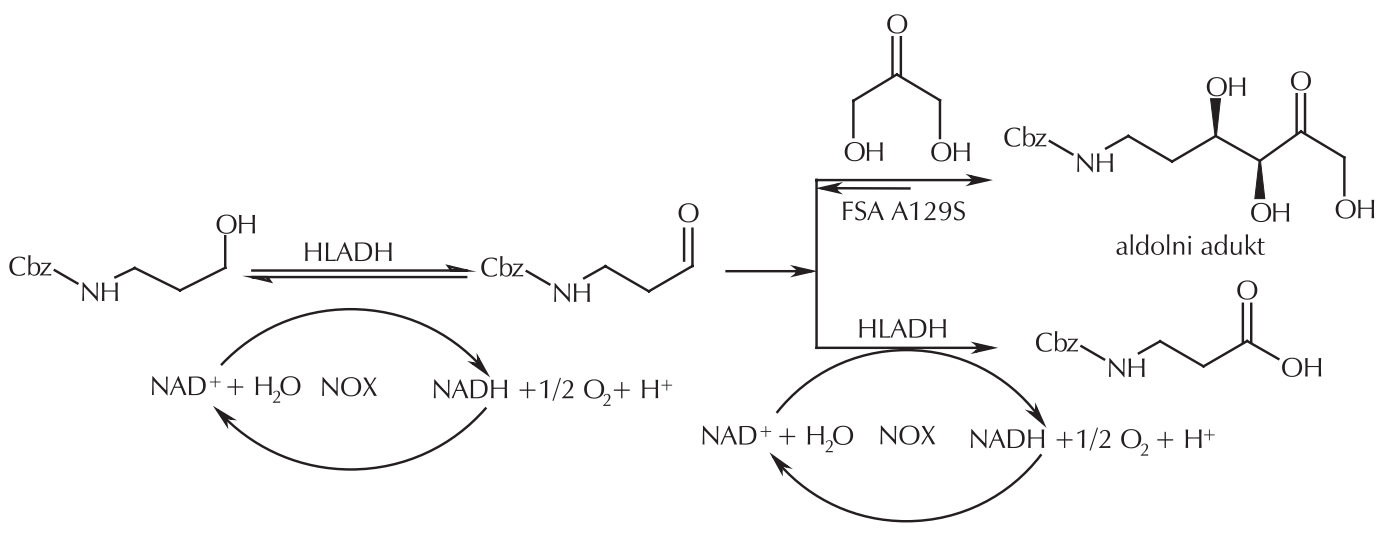

Shema 6 - Sinteza (3S,4R)-6-[(benziloksikarbonil)amino]-5,6-dideoksiheks-2-uloze ${ }^{49}$ Scheme 6 - Synthesis of (3S,4R)-6-[(benzyloxycarbonyl)amino]-5,6-dideoxyhex-2-ulose ${ }^{49}$ 

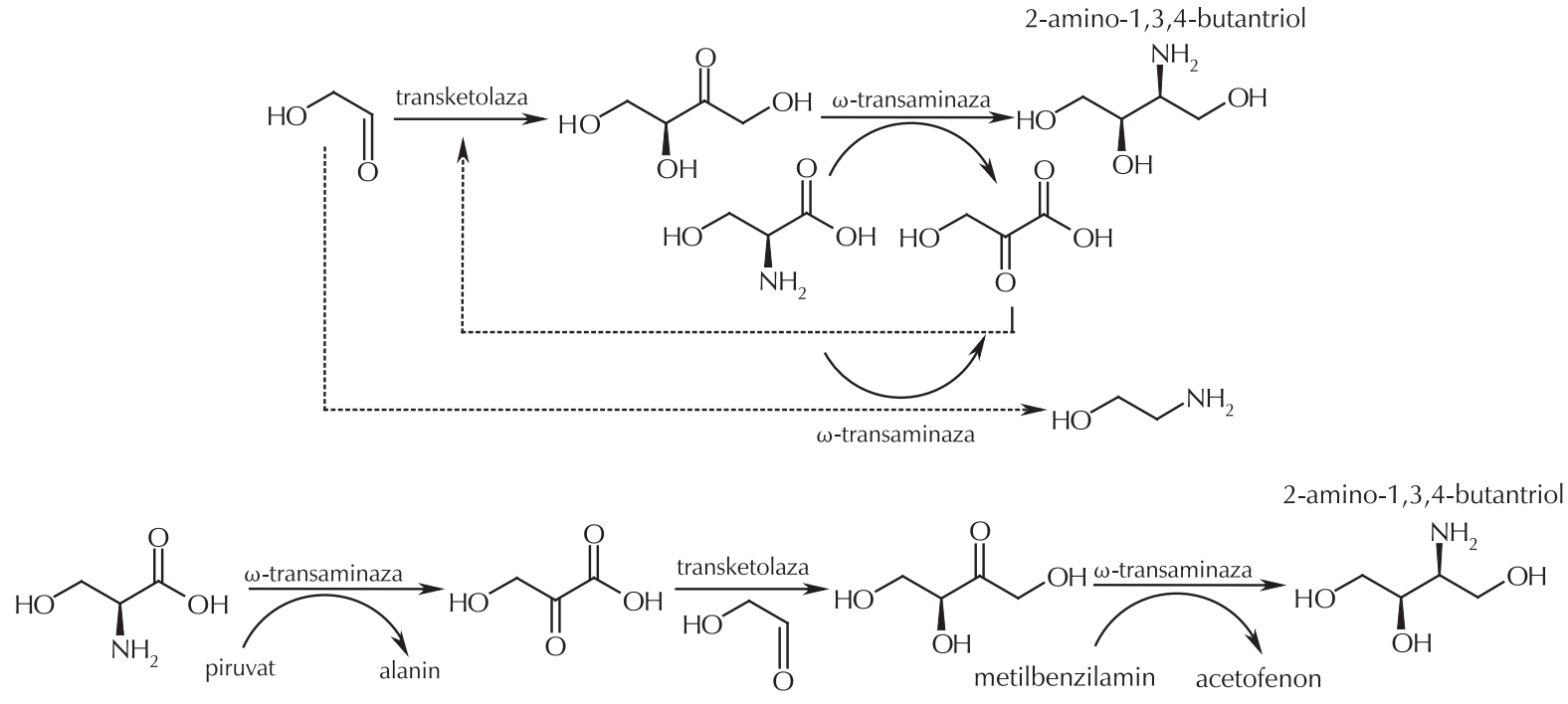

Shema 7 - Alternativni pristupi za sintezu 2-amino-1,3,4-butantriola ${ }^{39}$

Scheme 7 - Alternative approaches in the synthesis of 2-amino-1,3,4-butanetriol ${ }^{39}$

i koncentracije supstrata. Genetički algoritam omogućio je identifikaciju enzima koji najviše doprinose povećanju produktivnosti i iskorištenja na produktu te je utvrđeno da na uspješnost cijelog sustava najviše utječe zadnji reakcijski korak kataliziran hidrogenazom.

\section{Rasprava}

Pregled literature pokazuje sve češću primjenu inženjerskog pristupa prilikom proučavanja složenih biokemijskih sustava kao što su sintetski metabolički putovi, ${ }^{43,47}$ sinteza građevnih blokova i kemikalija za industrijsku primje$\mathrm{nu}, 34,38,39,41,42,45,49$ sintetski putovi za uporabu biomase u svrhu proizvodnje vodika ili njezine razgradnje za proizvodnju drugih vrijednih proizvoda, ${ }^{50-52}$ razgradnja toksičnih spojeva ${ }^{46}$ i biotransformacija šećera. ${ }^{9,43,44,48}$ Istraživanja prikazana u ovom preglednom radu pokazuju prednosti kinetičkog modeliranja, kao i prednosti primjene statističkih i stohastičkih metoda optimizacije. Primjena reakcijskog inženjerstva omogućuje lakšu i bržu optimizaciju složenih kaskadnih reakcija, sustava koji su sve zanimljiviji akademskoj zajednici i industriji. Tablica 1 sadržava dostupne procesne podatke koji pokazuju da je većina više-enzimskih sustava, uz neke iznimke, proučavana na mililitarskoj skali, uglavnom kao procesi u kotlastom reaktoru uz upotrebu relativno niskih koncentracija supstrata. To je i očekivano za modele reakcijskih sustava koji opisuju metaboličke procese in vitro, ali u drugim procesnim sustavima koncentracije bi trebale biti znatno više. Osim toga, brojni su nedostatci primjene procesa u kotlastom reaktoru, zbog čega se teži razvoju kontinuiranih procesa radi njihovih prednosti u industrijskom okruženju. ${ }^{57}$ Ipak, reaktorski sustav treba birati sukladno istraživanoj reakciji a poznavanje svih inhibicija i međuovisnosti prisutnih u sustavu može pomoći prilikom donošenja ispravne odluke. Razvijeni kinetički model može se kombinirati s bilancama tvari za različite reaktorske izvedbe, čime se bez provedbe dodatnih ekspe- rimenata može odabrati odgovarajuća izvedba reaktora za promatranu reakciju. Štoviše, model se može primjenjivati čak i obrnuto tako da se, počevši od odabranog tipa reaktora, pronađu početni reakcijski uvjeti s kojima se ostvaruju potrebne procesne veličine. Smanjenje operacijske stabilnosti enzima često je zanemareno prilikom istraživanja i modeliranja iako se radi o svojstvu enzima od ključne važnosti za industrijsku primjenu. Ukoliko je enzimska operacijska stabilnost poznata, enzim s niskom stabilnošću može se zamijeniti sa stabilnijim enzimom, a mogu se primijeniti i tehnike proteinskog inženjerstva u svrhu unaprjeđenja stabilnosti enzima. Na taj se način izazovi rada s nestabilnim biokatalizatorom mogu izbjeći u ranoj fazi razvoja procesa. Kao što se vidi iz prikazanih primjera iz literature, kinetičko modeliranje može se uspješno kombinirati sa sintetskom biologijom i proteinskim inženjerstvom. Metabolički putovi mogu se opisati i razumjeti kinetičkim modeliranjem. Dizajn genetički modificiranih mikroorganizama koji sadrže enzime, biokatalizatore više-enzimskih biotransformacija, može biti pojednostavljen i olakšan kinetičkim modeliranjem, pri čemu se koncentracije enzima u stanicama mogu podesiti na temelju podataka iz kinetičkog modela. Takva su istraživanja još u začetcima, zbog čega je brzina razvoja tih sustava za industrijsku upotrebu još uvijek ograničena.

Kinetička svojstva enzima omogućuju izbor odgovarajućih enzima u nove više-enzimske sustave, bez potrebe za dodatnim eksperimentalnim radom. Novi reakcijski putovi najprije se mogu ispitati in silico, nakon čega se donosi odluka o njihovom potencijalnom uspjehu i primjenjivosti. Dostupna znanstvena literatura i enzimska baza podataka BRENDA nude širok izbor supstrata i enzima za potencijalnu primjenu. Čak je u slučaju novih supstrata, o kojima podatci još nisu dostupni, moguće napraviti preliminarnu evaluaciju sustava upotrebljavajući poznate supstrate, iz čega se mogu donijeti zaključci utemeljeni na istraživačkom iskustvu. Potencijal eksperimentalnog istraživanja in silico iznimno je velik te iziskuje manje vremena i ulaganja za postizanje rezultata. 


\section{Zaključak}

Optimizacija više-enzimskih kaskadnih sustava ne bi bila moguća bez inženjerskog pristupa s obzirom na svoju kompleksnost i velik broj varijabli. Drugim riječima, metoda pokušaja i pogreške ne može se primijeniti na takve sustave, pogotovo ako se više-enzimski sustav razmatra za industrijsku primjenu. $U$ ovom radu prikazana su najnovija dostignuća na tom području te su istaknuti glavni izazovi. Modeliranje biokatalitičkih procesa još se uvijek relativno rijetko primjenjuje, što potkrjepljuje i broj literaturnih referencija u ovom radu vezanih uz modeliranje. Može se primijetiti da se porastom broja enzima upotrijebljenih $u$ reakcijskom sustavu, smanjuje broj istraživanja vezanih za taj sustav kao i koncentracija supstrata. Međutim, postoje i uspješni primjeri koji potvrđuju korisnost takvog pristupa. $\mathrm{U}$ mnogim se istraživanjima upotrebljavaju niske koncentracije supstrata u usporedbi s industrijskim zahtjevima, a većina njih ne uzima u obzir dostizanje relevantnih procesnih veličina potrebnih za industrijsku primjenu. Uz modeliranje, u ovom radu prikazani su i drugi inženjerski pristupi, koji mogu biti podjednako važni i primjenjivi. Najnovija postignuća i literatura iz tog područja ukazuju da taj pristup može imati obećavajuću budućnost, ali predstoji još mnogo truda. Većina je biokatalitičkih kaskadnih reakcija opisana u kotlastom reaktoru bez dodatka ili s dotokom supstrata, dok je industrijski zahtjev provođenje kontinuiranih procesa radi nižih troškova, stabilne kvalitete izlaznog proizvoda, visoke produktivnosti i lakšeg automatskog upravljanja procesom. Navedeni uvjeti tek se trebaju primijeniti $u$ istraživanjima, ali s obzirom na promjene i napredak postignut u posljednjem desetljeću može se očekivati da će više-enzimski kaskadni procesi imati svijetlu budućnost kako u znanosti tako i u industriji.

\section{ZAHVALA}

Autori zahvaljuju programu Europske nije Obzor 2020 Istraživanje i inovacije na financiranju projekta Carbazymes (br. ugovora 635595).

\section{Popis kratica i simbola \\ List of abbreviations and symbols}

C $\quad-$ koncentracija, $\mathrm{mmol} \mathrm{dm}^{-3}$

- concentration, $\mathrm{mmol} \mathrm{dm}^{-3}$

$Q_{v} \quad-$ volumna produktivnost, $\mathrm{gl}^{-1} \mathrm{~d}^{-1}$

- volume productivity, $\mathrm{gl}^{-1} \mathrm{~d}^{-1}$

V $\quad$ - volumen, I

- volume, I

X $\quad$ - konverzija supstrata, $\%$

- substrate conversion, \%

\section{Literatura}

References

1. A. Liese, K. Seelbach, C. Wandrey, Industrial biotransformations, 2. izdanje; Wiley-VCH Verlag $\mathrm{GmbH} \&$ Co. KGaA: Weinheim, 2006

2. W.-D. Fessner, What is the color of Your biocatalysis?, Adv. Synth. Catal. 347 (2005) 903-904, doi: https://doi. org/10.1002/adsc.200505121.

3. W. D. Fessner, Systems Biocatalysis: Development and engineering of cell-free "artificial metabolisms" for preparative multi-enzymatic synthesis, N. Biotechnol. 32 (2015) 658664, doi: https://doi.org/10.1016/j.nbt.2014.11.007.

4. J. M. Woodley, Integrating protein engineering with process design for biocatalysis, Philos. Trans. A. Math. Phys. Eng. Sci. 376 (2018) 20170062, doi: https://doi.org/10.1098/ rsta.2017.0062.

5. Z. Findrik, Đ. Vasić-Rački, Overview on reactions with multi-enzyme systems, Chem. Biochem. Eng. Q. 23 (2009) 545-553.

6. J. H. Schrittwieser, S. Velikogne, M. Hall, W. Kroutil, Artificial biocatalytic linear cascades for preparation of organic molecules, Chem. Rev. 118 (2018) 270-348, doi: https://doi. org/10.1021/acs.chemrev.7b00033.

7. R. Xue, J. M. Woodley, Process technology for multi-enzymatic reaction systems, Bioresour. Technol. 115 (2012) 183195, doi: https://doi.org/10.1016/j.biortech.2012.03.033.

8. S. Riva, W.-D. Fessner, Cascade biocatalysis, Wiley-VCH Verlag $\mathrm{GmbH} \&$ Co. KGaA: Weinheim, 2014.

9. C. Zhong, P. Wei, Y.-H. P. Zhang, A kinetic model of one-pot rapid biotransformation of cellobiose from sucrose catalyzed by three thermophilic enzymes, Chem. Eng. Sci. 161 (2017) 159-166, doi: https://doi.org/10.1016/j.ces.2016.11.047.

10. R. H. Ringborg, J. M. Woodley, The application of reaction engineering to biocatalysis, React. Chem. Eng. 1 (2016) 1022, doi: https://doi.org/10.1039/c5re00045a.

11. P. Tufvesson, J. Lima-Ramos, N. A. Haque, K. V. Gernaey, J. M. Woodley, Advances in the process development of biocatalytic processes, Org. Process Res. Dev. 17 (2013) 1233 1238, doi: https://doi.org/10.1021/op4001675.

12. S. Leuchs, J. Lima-Ramos, L. Greiner, N. Al-Haque, P. Tufvesson, J. M. Woodley, Reaction engineering of biocatalytic enantioselective reduction: A case study for aliphatic ketones, Org. Process Res. Dev. 17 (2013) 1027-1035, doi: https://doi.org/10.1021/op400117t.

13. G. Zhang, M. B. Quin, C. Schmidt-Dannert, Self-assembling protein scaffold system for easy in vitro coimmobilization of biocatalytic cascade enzymes, ACS Catal. 8 (2018) 5611 5620, doi: https://doi.org/10.1021/acscatal.8b00986.

14. R. A. Sheldon, P. C. Pereira, Biocatalysis engineering: The big picture, Chem. Soc. Rev. 46 (2017) 2678-2691, doi: https:// doi.org/10.1039/c6cs00854b.

15. R. A. Sheldon, J. M. Woodley, Role of biocatalysis in sustainable chemistry, Chem. Rev. 118 (2018) 801-838, doi: https:// doi.org/10.1021/acs.chemrev.7b00203.

16. S. Heiden, F. Eiden, J. M. Woodley, A. Schmid, ChemBioTec - linking chemistry, biology and engineering, J. Mol. Catal. B: Enzym. 103 (2014) 1, doi: https://doi.org/10.1016/j.mol- 
catb.2014.02.011

17. D. G. Blackmond, Reaction progress kinetic analysis: a powerful methodology for mechanistic studies of complex catalytic reactions, Angew. Chem. Int. Ed. Engl. 44 (2005) 4302-4320, doi: https://doi.org/10.1002/anie.200462544.

18. M. Sudar, Đ. Vasić-Rački, M. Müller, A. Walter, Z. F. Blažević, Mathematical model of the MenD-catalyzed 1,4-addition (Stetter reaction) of alpha-ketoglutaric acid to acrylonitrile, J. Biotechnol. 268 (2018) 71-80, doi: https://doi. org/10.1016/j.jbiotec.2018.01.013.

19. Đ. Vasić-Rački, J. Bongs, U. Schorken, G. A. Sprenger, A. Liese, Modeling of reaction kinetics for reactor selection in the case of L-erythrulose synthesis, Bioprocess Biosyst. Eng. 25 (2003) 285-290, doi: https://doi.org/10.1007/s00449-002-0312-y.

20. R. K. Mitra, J. M. Woodley, M. D. Lilly, Escherichia coli transketolase-catalyzed carbon-carbon bond formation: biotransformation characterization for reactor evaluation and selection, Enzyme Microb. Technol. 22 (1998) 64-70, doi: https://doi.org/10.1016/s0141-0229(97)00106-3.

21. R. K. Mitra, J. M. Woodley, M. D. Lilly, Process design implications of aldehyde properties on transketolase-catalysed condensations, Biocatal. Biotransfor. 17 (1999) 21-36, doi: https://doi.org/10.3109/10242429909003204.

22. J. Bongs, D. Hahn, U. Schörken, G. A. Sprenger, U. Kragl, C. Wandrey, Continuous production of erythrulose using transketolase in a membrane reactor, Biotechnol. Lett. 19 (1997) 213-216, doi: https://doi.org/10.1023/a:1018341204341.

23. N. A. Sayar, B. H. Chen, G. J. Lye, J. M. Woodley, Modelling and simulation of a transketolase mediated reaction: Sensitivity analysis of kinetic parameters, Biochem. Eng. J. 47 (2009) 1-9, doi: https://doi.org/10.1016/j.bej.2009.02.011.

24. A. Vrsalović Presečki, Đ. Vasić-Rački, Mathematical modelling of the dehydrogenase catalyzed hexanol oxidation with coenzyme regeneration by $\mathrm{NADH}$ oxidase, Process Biochem. 44 (2009) 54-61, doi: https://doi.org/10.1016/j. procbio.2008.09.007.

25. M. C. Hogan, J. M. Woodley, Modelling of two enzyme reactions in a linked cofactor recycle system for chiral lactone synthesis, Chem. Eng. Sci. 55 (2000) 2001-2008, doi: https://doi.org/10.1016/s0009-2509(99)00478-9.

26. M. Braun, H. Link, L. Liu, R. D. Schmid, D. Weuster-Botz, Biocatalytic process optimization based on mechanistic modeling of cholic acid oxidation with cofactor regeneration, Biotechnol. Bioeng. 108 (2011) 1307-1317, doi: https://doi. org/10.1002/bit.23047.

27. N. H. Pham, F. Hollmann, D. Kracher, M. Preims, D. Haltrich, R. Ludwig, Engineering an enzymatic regeneration system for NAD(P)H oxidation, J. Mol. Catal. B: Enzym. 120 (2015) 38-46, doi: https://doi.org/10.1016/j.molcatb.2015.06.011.

28. Z. Findrik, Đ. Vasić-Rački, S. Lutz, T. Daussmann, C. Wandrey, Kinetic modeling of acetophenone reduction catalyzed by alcohol dehydrogenase from Thermoanaerobacter sp., Biotechnol. Lett. 27 (2005) 1087-1095, doi: https://doi. org/10.1007/s10529-005-8455-y.

29. Z. Findrik, I. Šimunović, Đ. Vasić-Rački, Coenzyme regeneration catalyzed by $\mathrm{NADH}$ oxidase from Lactobacillus brevis in the reaction of L-amino acid oxidation, Biochem. Eng. J. 39 (2008) 319-327, doi: https://doi.org/10.1016/j. bej.2007.10.003.

30. V. Kaswurm, W. V. Hecke, K. D. Kulbe, R. Ludwig, Guidelines for the application of $\mathrm{NAD}(\mathrm{P}) \mathrm{H}$ regenerating glucose dehydrogenase in synthetic processes, Adv. Synth. Catal. 355 (2013) 1709-1714, doi: https://doi.org/10.1002/ adsc. 201200959.

31. A. Švarc, D. Valinger, Đ. Vasić-Rački, A. Vrsalović Presečki,
Stereoselective synthesis of phenylpropane 1,2-diols from (S)-2-hydroxypropiophenone by NADH-dependent oxidoreductases, Biochem. Eng. J. 103 (2015) 250-255, doi: https://doi.org/10.1016/j.bej.2015.07.012.

32. F. M. Bastos, T. K. França, G. D. C. Machado, G. F. Pinto, E. G. Oestreicher, L. M. C. Paiva, Kinetic modelling of coupled redox enzymatic systems for in situ regeneration of NADPH, J. Mol. Catal. B: Enzym. 19-20 (2002) 459-465, doi: https:// doi.org/10.1016/s1381-1177(02)00199-6.

33. C. Mateo, B. Fernandes, F. van Rantwijk, A. Stolz, R. A. Sheldon, Stabilisation of oxygen-labile nitrilases via co-aggregation with poly(ethyleneimine), J. Mol. Catal. B: Enzym. 38 (2006) 154-157, doi: https://doi.org/10.1016/j.molcatb.2005.12.007.

34. W. Van Hecke, D. Haltrich, B. Frahm, H. Brod, J. Dewulf, H. Van Langenhove, $R$. Ludwig, A biocatalytic cascade reaction sensitive to the gas-liquid interface: Modeling and upscaling in a dynamic membrane aeration reactor, J. Mol. Catal. B: Enzym. 68 (2011) 154-161, doi: https://doi.org/10.1016/j. molcatb.2010.10.004.

35. Z. Findrik, A. Vrsalović Presečki, Đ. Vasić-Rački, The influence of aeration on activity and operational stability of two snake venom amino acid oxidases, Biochem. Eng. J. 60 (2012) 9198, doi: https://doi.org/10.1016/j.bej.2011.10.008.

36. A. Švarc, D. Valinger, Đ. Vasić-Rački, A. Vrsalović Presečki, Stereoselective synthesis of (1S,2S)-1-phenylpropane-1,2-diol by cell-free extract of Lactobacillus brevis, Green Process. Synth. 5 (2016) 153-161, doi: https://doi.org/10.1515/gps2015-0100.

37. B. H. Chen, A. Sayar, U. Kaulmann, P. A. Dalby, J. M. Ward, J. M. Woodley, Reaction modelling and simulation to assess the integrated use of transketolase and $\omega$-transaminase for the synthesis of an aminotriol, Biocatal. Biotransfor. 24 (2009) 449457, doi: https://doi.org/10.1080/10242420601068668.

38. L. Rios-Solis, P. Morris, C. Grant, A. O. O. Odeleye, H. C. Hailes, J. M. Ward, P. A. Dalby, F. Baganz, G. J. Lye, Modelling and optimisation of the one-pot, multi-enzymatic synthesis of chiral amino-alcohols based on microscale kinetic parameter determination, Chem. Eng. Sci. 122 (2015) 360-372, doi: https://doi.org/10.1016/j.ces.2014.09.046.

39. M. F. Villegas-Torres, J. M. Ward, F. Baganz, Optimisation of enzyme cascades for chiral amino alcohol synthesis in aid of host cell integration using a statistical experimental design approach, J. Biotechnol. 281 (2018) 150-160, doi: https:// doi.org/10.1016/j.jbiotec.2018.07.014

40. Y. Zheng, Z. Pan, R. Zhang, B. M. Jenkins, Kinetic modeling for enzymatic hydrolysis of pretreated creeping wild ryegrass, Biotechnol. Bioeng. 102 (2009) 1558-1569, doi: https:// doi.org/10.1002/bit.22197.

41. C. Scherkus, S. Schmidt, U. T. Bornscheuer, H. Gröger, S. Kara, A. Liese, A fed-batch synthetic strategy for a three-step enzymatic synthesis of poly- $\epsilon$-caprolactone, ChemCatChem. 8 (2016) 3446-3452, doi: https://doi.org/10.1002/ cctc. 201600806.

42. S. Milker, M. J. Fink, N. Oberleitner, A. K. Ressmann, U. T. Bornscheuer, M. D. Mihovilovic, F. Rudroff, Kinetic modeling of an enzymatic redox cascade in vivo reveals bottlenecks caused by cofactors, ChemCatChem. 9 (2017) 3420-3427, doi: https://doi.org/10.1002/cctc.201700573.

43. N. Ishii, Y. Suga, A. Hagiya, H. Watanabe, H. Mori, M. Yoshino, M. Tomita, Dynamic simulation of an in vitro multi-enzyme system, FEBS Lett. 581 (2007) 413-420, doi: https:// doi.org/10.1016/j.febslet.2006.12.049.

44. A. C. Mafra, F. F. Furlan, A. C. Badino, P. W. Tardioli, Gluconic acid production from sucrose in an airlift reactor using a multi-enzyme system, Bioprocess Biosyst. Eng. 38 (2015) 
671-680, doi: https://doi.org/10.1007/s00449-014-1306-2.

45. Z. Findrik, Đ. Vasić-Rački, Biotransformation of D-methionine into L-methionine in the cascade of four enzymes, Biotechnol. Bioeng. 98 (2007) 956-967, doi: https://doi. org/10.1002/bit.21501.

46. P. Dvorak, N. P. Kurumbang, J. Bendl, J. Brezovsky, Z. Prokop, J. Damborsky, Maximizing the efficiency of multienzyme process by stoichiometry optimization, ChemBioChem. 15 (2014) 1891-1895, doi: https://doi.org/10.1002/ cbic. 201402265 .

47. T. F. T. Rexer, A. Schildbach, J. Klapproth, A. Schierhorn, R. Mahour, M. Pietzsch, E. Rapp, U. Reichl, One pot synthesis of GDP-mannose by a multi-enzyme cascade for enzymatic assembly of lipid-linked oligosaccharides, Biotechnol. Bioeng. 115 (2018) 192-205, doi: https://doi.org/10.1002/ bit.26454.

48. C. Hoh, G. Dudziak, A. Liese, Optimization of the enzymatic synthesis of O-glycan core 2 structure by use of a genetic algorithm, Bioorg. Med. Chem. Lett. 12 (2002) 1031-1034, doi: https://doi.org/10.1016/s0960-894x(02)00087-2.

49. M. Sudar, Z. Findrik, Đ. Vasić-Rački, A. Soler, P. Clapés, A new concept for production of $(3 S, 4 R)-6$-[(benzyloxycarbonyl)amino]-5,6-dideoxyhex-2-ulose, a precursor of D-fagomine, RSC Adv. 5 (2015) 69819-69828, doi: https://doi. org/10.1039/c5ra14414k.

50. J. A. Rollin, J. Martin del Campo, S. Myung, F. Sun, C. You, A. Bakovic, R. Castro, S. K. Chandrayan, C. H. Wu, M. W. Adams, R. S. Senger, Y. H. Zhang, High-yield hydrogen production from biomass by in vitro metabolic engineering: Mixed sugars coutilization and kinetic modeling, Proc. Natl. Acad. Sci. USA 112 (2015) 4964-4969, doi: https://doi.org/10.1073/ pnas. 1417719112.
51. I. Ardao, A.-P. Zeng, In silico evaluation of a complex multi-enzymatic system using one-pot and modular approaches: Application to the high-yield production of hydrogen from a synthetic metabolic pathway, Chem. Eng. Sci. 87 (2013) 183-193, doi: https://doi.org/10.1016/j.ces.2012.10.005.

52. E. Rosini, C. Allegretti, R. Melis, L. Cerioli, G. Conti, L. Pollegioni, P. D'Arrigo, Cascade enzymatic cleavage of the $\beta$-O4 linkage in a lignin model compound, Catal. Sci. Technol. 6 (2016) 2195-2205, doi: https://doi.org/10.1039/ c5cy01591j.

53. W. Van Hecke, A. Bhagwat, R. Ludwig, J. Dewulf, D. Haltrich, $H$. Van Langenhove, Kinetic modeling of a bi-enzymatic system for efficient conversion of lactose to lactobionic acid, Biotechnol. Bioeng. 102 (2009) 1475-1482, doi: https:// doi.org/10.1002/bit.22165.

54. D. Weuster-Botz, Experimental design for fermentation media development: Statistical design or global random search?, J. Biosci. Bioeng. 90 (2000) 473-483, doi: https:// doi.org/10.1016/s1389-1723(01)80027-x.

55. X. Ye, Y. Wang, R. C. Hopkins, M. W. Adams, B. R. Evans, J. R. Mielenz, Y. H. Zhang, Spontaneous high-yield production of hydrogen from cellulosic materials and water catalyzed by enzyme cocktails, ChemSusChem. 2 (2009) 149-152, doi: https://doi.org/10.1002/cssc.200900017.

56. S. M. Kotay, D. Das, Biohydrogen as a renewable energy resource - Prospects and potentials, Int. J. Hydrogen Energ. 33 (2008) 258-263, doi: https://doi.org/10.1016/j. ijhydene.2007.07.031.

57. U. Kragl, Đ. Vasić-Rački, C. Wandrey, Continuous production of L-tert-leucine in series of two enzyme membrane reactors, Bioprocess Eng. 14 (1996) 291-297, doi: https://doi. org/10.1007/bf00369472.

\section{SUMMARY \\ Application of Mathematical Modelling in Development of Enzymatic Cascade Reactions \\ Nevena Milčić, Morana Česnik, Martina Sudar, and Zvjezdana Findrik Blažević*}

Today, systems biocatalysis, i.e., the implementation of cascade reactions that mimic cellular metabolic pathways, is increasingly being used. Cascade reactions have numerous advantages over traditional chemical processes; however, in order to successfully optimize and transfer such complex systems to a larger, industrial scale, it is necessary to apply reaction engineering. This review paper provides examples of the successful application of mathematical modelling in development of enzymatic cascade reactions that demonstrate the importance and potential of this methodology.

\section{Keywords}

Reaction engineering, biocatalysis, modelling, optimization, multi-enzymatic systems

University of Zagreb

Faculty of Chemical Engineering and Technology

Savska c. 16

HR-10000 Zagreb, Croatia
Review

Received July 30, 2019 Accepted August 20, 2019 